\title{
Clinical researches
}

\section{ДИНАМІКА ПОКАЗНИКІВ ЛІПІДНОГО СПЕКТРУ КРОВІ У ДІТЕЙ ІЗ ЮВЕНІЛЬНИМ ІДІОПАТИЧНИМ АРТРИТОМ 3 УРАХУВАННЯМ БАЗИСНОЇ ТЕРАПІЇ}

\author{
Богмат Л. Ф., Ніконова В. В., Шевченко Н. С., Головко Т. О., Бессонова І. М.
}

Резюме. У пацієнтів із ревматоїдним артритом ризик серцево-судинних захворювань, які пов'язані 3 атеросклерозом, значно збільшується у порівнянні з загальною популяцією. Дослідження когорти дітей та дорослих молодого віку свідчить про те, що атеросклеротичний процес, як правило, починається задовго до його клінічної маніфестації, а ступінь змін судин пов'язана як 3 кількістю факторів ризику, так і 3 їх інтенсивністю. Використання базисних препаратів у ревматологічних хворих сприяло зниженню кардіоваскулярної смертності, переважно за рахунок ліквідації активності процесу, яка сама по собі є індуктором виникнення та прогресування атеросклерозу.

Мета дослідження - встановити характер змін ліпідного спектру крові у дітей із ювенільний ідіопатичний артрит під впливом базисної терапії.

Об'скт і методи дослідження. Обстежено 85 дітей (8-18 років), хворих на ювенільний ідіопатичний артрит з оліго- $(61,5 \%)$ та поліартикулярним $(38,5 \%)$ варіантами захворювання, двічі 3 інтервалом в 1 рік. Показники ліпідного спектру крові визначали за рівнем: загального холестерину, тригліцеридів, ліпопротеїдів високої щільності та коефіцієнту атерогенності ферментативним методом на біохімічному автоматичному аналізаторі-фотометрі А25, ліпопротеїдів низької та дуже низької щільності розрахунковим методом.

Результати дослідження. Аналіз ліпідограм в цілому по групі показав, що у пацієнтів із ювенільним ідіопатичним артритом вірогідно вищими були показники загального холестеріну (p < 0,05), тенденція до підвищення рівня тригліцеридів, холестерину низької щільності та дуже низької щільності, що призводило до зростання рівня коефіцієнту атерогенності. При аналізі ліпідного спектру крові через рік відмічено тенденцію до зниження рівня атерогенних та підвищення антиатерогенних фракцій ліпідного спектру із нормалізацією коефіцієнту атерогенності. В групі хворих, які отримували монотерапію метотрексатом, через один рік суттєвих змін в ліпідному спектрі крові не відмічено. На тлі комбінованої базисної терапії відбувається нормалізація ліпідного спектру крові, а саме зниження загального холестеріну, приріст ліпопротеїдів високої щільності, зниження рівня тригліцеридів ( $<0,01)$, холестерину низької щільності $(\mathrm{p}<0,05)$, як наслідок, значне зниження коефіцієнту атерогенності $(\mathrm{p}<0,01)$.

Висновок. Динаміка змін показників ліпідного спектру крові у дітей із ювенільним ідіопатичним артритом підтверджує необхідність використання комбінованої базисної терапії не тільки для контролю основного патологічного процесу, а й для профілактики розвитку атерогенних дисліпопротеїдемій.

КЛЮЧОВІ СЛОВА: ювенільний ідіопатичний артрит, ліпідний спектр, терапія, діти

\section{ІНФОРМАЦІЯ ПРО АВТОРІВ}

Богмат Людмила Феодосіївна, д. мед. н., професор, зав. відділу ревматології та коморбідних станів, ДУ «Інститут охорони здоров'я дітей та підлітків НАМН України», проспект Ювілейний, 52 А, Харків, Україна, 61118; професор кафедри педіатрії № 2, Харківський національний університет імені В. Н. Каразіна, майдан Свободи, 4, Харків, Україна, 61022. e-mail: bogmatLF@gmail.com,_ORCID ID:_https://orcid.org/0000-0001-5144-3686 Ніконова Вікторія Вадимівна, к. мед. н., старший науковий співробітник відділу ревматології та коморбідних станів, ДУ «Інститут охорони здоров'я дітей та підлітків НАМН України», проспект Ювілейний, 52 А, Харків, Україна, 61118, e-mail: viktoriavvn@ gmail.com ORCID ID: https://orcid.org/0000-0001-8269-6176

Шевченко Наталя Станіславівна, д. мед. н., зав. каф. педіатрії № 2, Харківський національний університет імені В. Н. Каразіна, майдан Свободи, 4, Харків, Україна, 61022; д. мед. н., ведучий науковий співробітник відділу ревматології та коморбідних станів, ДУ «Інститут охорони здоров'я дітей та підлітків НАМН України», проспект Ювілейний, 52 А, Харків, Україна, 61118. e-mail: natalia.shevchenko@karazin.ua, ORCID ID: https://orcid.org/00000003-4407-6050 
Головко Тетяна Олексіївна, к. мед. н., доцент кафедри педіатрії № 2, Харківський національний університет імені В. Н. Каразіна, майдан Свободи, 4, Харків, Україна, 61022. e-mail: golovko@karazin.ua, ORCID ID: https://orcid.org/0000-0003-3815-7874

Бессонова Ірина Миколаївна, старший науковий співробітник відділу ревматології та коморбідних станів, ДУ «Інститут охорони здоров'я дітей та підлітків НАМН України», проспект Ювілейний, 52 А, Харків, Україна, 61118 , доцент кафедри педіатрії, Харківський національний університет імені В. Н. Каразіна, майдан Свободи, 4 , Харків, Україна, 61022. e-mail: irina_bessonova@yahoo.com, ORCID ID: https://orsid.org/0000-0002-8473-8365

У дорослих пацієнтів із ревматоїдним артритом (РА) ризик серцево-судинних захворювань (СС3), який пов'язаний 3 атеросклерозом, значно збільшується у порівнянні з загальною популяцією [1, 2, 3]. Дослідження когорти дітей та дорослих молодого віку свідчать про те, що атеросклеротичний процес, як правило, починається задовго до його клінічної маніфестації, а ступінь атеросклеротичних змін судин пов'язана як 3 кількістю факторів ризику, так і з їх інтенсивністю [4].

Наукові розробки останніх років підтвердили, що сам ревматичний процес може змінювати ліпідний профіль із підвищенням рівня загального холестерину, холестерину ліпопротеїдів низької щільності, тригліцеридів і зниженням холестерину ліпопротеїдів високої щільності, і він стає проатерогенним [1, 10]. Особлива роль у цих процесах належить прозапальним цитокінам (інтерлейкін-1 i 6, фактор некрозу пухлини-альфа (ФНО- $\alpha)$ ), які підтримують розвиток i прогресування не тільки ревматичного процесу, але й атеросклерозу $[2,6]$. Через взаємодію холестерину 3 запальними цитокінами процес формування дисліпідемій у пацієнтів із РА більш складний, ніж у осіб в загальній популяції. У деяких хворих, при наявності ознак активного запального процесу, рівень загального холестерину і ХС ЛПНЩ знижується, із паралельним парадоксальним набуттям прозапальних властивостей ліпопротеїдами високої щільності (ЛПВЩ). Це прискорює формування дисфункції ендотелію і утворення бляшок. Подібний стан визначено як «ліпідний парадокс при РА», який характеризується особливим гіполіпідемічним ефектом системного запалення, пов'язаного 3 ревматичним процесом $[7,8]$.

Прояви дисліпопротеїдемії та формування атеросклеротичних уражень в подальшому можуть посилюватись на тлі протизапальної терапії. Так, у хворих із P3, які приймають глюкокортикостероїди (ГКС), частіше виявляються атеросклерозтичні бляшки в сонних артеріях, а також значно раніше відбувається потовщення комплексу інтіма-медіа (КІМ) сонних артерій у порівнянні з пацієнтами, які не отримували ГКС. ГКС-терапія призводить до накопичення також i традиційних кардіоваскулярних факторів ризику порушення метаболізму глюкози та інсуліну, підвищення артеріального тиску, збільшення маси тіла [10].

Разом із тим відомо, що негативний вплив на судинну стінку, згортання крові і артеріальний тиск лікарських засобів, які $є$ базисними у хворих на ревматичні захворювання, може компенсуватися «антиатерогенною» їх дією за рахунок ліквідації «запального» компоненту атеротромбозу. Крім того, використання базисних препаратів у ревматологічних хворих сприяло зниженню кардіоваскулярної смертності, переважно за рахунок ліквідації активності процесу, яка сама по собі $\epsilon$ індуктором виникнення та прогресування атеросклерозу, персистуючої тромбоцитарної агрегації, дисфункції ендотелію із ремоделюванням артерій [11, 12].

Тому, метою даного дослідження було - встановити характер змін ліпідного спектру крові у дітей із ЮІА під впливом базисної терапії.

\section{ОБ’ЄМ ТА МЕТОДИ ДОСЛІДЖЕННЯ}

Обстежено 85 дітей (8-18 років) хворих на ЮІА 3 оліго- $(61,5 \%)$ та поліартикулярним $(38,5 \%)$ варіантами захворювання, в процесі динамічного спостереження 3 інтервалом в один рік. Серед пацієнтів переважали особи жіночої статі: 63 (66,2 \%) дівчинки та $22(33,8 \%)$ хлопчика $(\mathrm{p}<0,05)$.

Для встановлення діагнозу керувалися протоколами діагностики та лікування кардіоревматологічних хвороб у дітей 
(Наказ МО3 № 362 від 2005 р.), та «Уніфікований клінічний протокол медичної допомоги дітям, хворим на ювенільний артрит» (Наказ МО3 від 22.10 .2012 р. № 832). Проводилось клініко-лабораторне дослідження: клінічне обстеження пацієнтів, визначення ступеня активності захворювання (показники активності запального процесу (Cреактивний протеїн (СРБ), фібриноген $(Ф Г))$, наявність імунологічних маркерів автоімунного процесу (антинуклеарні антитіла (АНА), ревматоїдний фактор $($ РФ)), рентгенологічне та ультразвукове обстеження суглобів.

Показники ліпідного спектру крові визначали за рівнем загального холестерину (3X), тригліцеридів (ТГ) ліпопротеїдів високої щільності (XC ЛПВЩ) та коефіцієнту атерогенності (КА) ферментативним (CHOD-PAPP) методом на біохімічному автоматичному аналізаторі-фотометрі А 25, ліпопротеїдів низької (ХС ЛПНЩ) та дуже низької щільності (ХС ЛПДНЩ) розрахунковим методом. Показники рівня ЗХС в сироватці крові визначались ферментативним методом в діапазоні від $2,0-10,0$ ммоль/л та похибкою $\pm 7 \%$, ТГ в діапазоні від $0,15-4,5$ ммоль/л 3 похибкою $\pm 7 \%$.

$$
\text { Розрахунок } \quad \text { ХC } \quad \text { ЛПДНЩ }
$$

проводився за формулою 1 :

ХС ЛПДНЩ= $\frac{\text { Тригліцериди }}{2,2 \text { (тригліцериди менше } 4,2 \text { ммоль/л) }}(1)$

При показниках ТГ більше 4,2 ммоль/л, ХС ЛПДНЩ не розраховувались.

Розрахунок ХС ЛПНЩ проводивя за формулою 2:

ХС лПнщ = 3ХС - (ХС ЛПднЩ+Хс ЛПВЩ)

Показники коєфіціенту атерогеності (КА) визначалися за формулою 3 :

КА $=\frac{\text { (эагальний холестерин }- \text { ЛПвщ) }}{\text { ЛПВЩ }}$

Статистична обробка матеріалу проведена 3 використанням пакету прикладних програм (MSExcel, SPSS). Для визначення достовірності відмінностей показників використовувались параметричні (t-критерій Ст'юдента (p), кутового перетворення Фішера) та непараметричні критерії (Вілкоксона-Манна-Уітні), а для визначення взаємозв'язку та взаємовпливу окремих складових проводився кореляційний та регресійний аналізи. Критичний рівень значимості для перевірки статистичних гіпотез при порівнянні груп та логістичному аналізі приймався рівним 0,05 .

\section{РЕЗУЛЬТАТИ ДОСЛІДЖЕННЯ}

Аналіз ліпідограм дітей, хворих на ЮІА, показав, що показники ЗХС були вірогідно вищими $(\mathrm{p}<0,05)$, рівні ТГ, ХС ЛПНЩ та ХС ЛПДНЩ мали тенденцію до підвищення, в порівнянні з контрольною групою. Це призводило до зростання рівня КА - показника атерогенності виявлених дисліпопротеїдемій. Аналіз ліпідного спектру крові через рік виявив тенденцію до зниження рівня атерогенних та підвищення антиатерогенних фракцій ліпідного спектру із нормалізацією КА (табл. 1).

Для подальшого аналізу виділено підгрупи дітей, в яких реєструвались основні несприятливі зміни ліпідного спектру крові, а саме група хворих 3 високими рівнями ХС ЛПНЩ (понад 3,20 ммоль/л), група з високими ТГ (понад 1,30 ммоль/л) та група із низьким рівнем ХС ЛПВЩ (менш 1,03 ммоль/л).

В підгрупі хворих з високим рівнем ХС ЛПНЩ (10 осіб) виявлено, крім підвищеного рівня ЗХC, тенденцію до підвищення рівня ТГ та КА. При обстеженні через рік, на тлі лікування базисними препаратами основного захворювання (метотрексат, анти-ФНО), відбувалось зниження рівня $3 \mathrm{XC}$ та ХC ЛПНЩ (p < 0,05), тенденція до зниження ТГ та підвищення антиатерогенної фракції ХC ЛПВЩ i, як наслідок, нормалізація KA.

В групі з високим рівнем ТГ (7 осіб), при першому дослідженні, зареєстровано підвищення рівня $3 \mathrm{XC}$ та високий рівень $\mathrm{XC}$ ЛПНЩ. При обстеженні через рік у цих дітей відбувався ще більший приріст рівня ТГ $(\mathrm{p}<0,05)$ із підвищенням рівня ХC ЛПДНЩ $(\mathrm{p}<0,05)$. Тобто, не дивлячись на те, що всі діти отримували базисну терапію і активність ЮІА у них була мінімальною, у частини 3 них зберігалися стійкі порушення в ліпідному спектрі крові за рахунок ТГ. Слід зазначити, що у всіх хворих з цієї підгрупи 
виявлено серопозитивний за АНА варіант ЮІА. Показники ліпідного спектру крові у хворих із ЮІА приведены у табл. 1.

Таблиця 1

Показники ліпідного спектру крові у хворих із ЮІА при першому дослідженні та в динаміці спостереження (через 12 місяців), $\mathrm{M} \pm \mathbf{m}$

\begin{tabular}{|c|c|c|c|c|c|c|}
\hline & $\begin{array}{c}\text { ЗХС, } \\
\text { ммоль/л }\end{array}$ & $\begin{array}{c}\text { ХС ЛПВЩ, } \\
\text { ммоль/л }\end{array}$ & $\begin{array}{l}\text { ХС ЛПНЩ, } \\
\text { ммоль/л }\end{array}$ & $\begin{array}{l}\text { Тригліцеріди, } \\
\text { ммоль/л }\end{array}$ & $\begin{array}{c}\text { ХСЛПДНЩ, } \\
\text { ммоль/л }\end{array}$ & $\begin{array}{c}\text { Коефіцієнт } \\
\text { атерогенності, } \\
\text { у.о. }\end{array}$ \\
\hline \multicolumn{7}{|c|}{ Показники ліпідного спектру у хворих із ЮІА в динаміці спостереження (через 12 місяців) } \\
\hline $\begin{array}{c}1 \text { дослідження } \\
\mathrm{n}-85\end{array}$ & $5,01 \pm 0,10^{*}$ & $1,48 \pm 0,06$ & $3,02 \pm 0,15$ & $1,03 \pm 0,07 *$ & $0,52 \pm 0,05^{*}$ & $2,37 \pm 0,17$ \\
\hline $\begin{array}{l}2 \text { дослідження } \\
\mathrm{n}-85\end{array}$ & $4,69 \pm 0,11$ & $1,56 \pm 0,05$ & $2,73 \pm 0,16$ & $0,88 \pm 0,05$ & $0,41 \pm 0,02$ & $2,04 \pm 0,11$ \\
\hline $\begin{array}{c}\text { Група } \\
\text { контролю } \\
\mathrm{n}-19\end{array}$ & $3,8 \pm 0,20$ & $1,32 \pm 0,08$ & $2,34 \pm 0,10$ & $0,72 \pm 0,06$ & $0,14 \pm 0,01$ & $1,87 \pm 0,15$ \\
\hline \multicolumn{7}{|c|}{$\begin{array}{c}\text { Показники ліпідного спектру у хворих із ЮІА з високим рівнем ХС ЛПНЩ } \\
\text { в динаміці спостереження (через } 12 \text { місяців) }\end{array}$} \\
\hline $\begin{array}{l}1 \text { дослідження } \\
\mathrm{n}-20\end{array}$ & $5,62 \pm 0,32$ & $1,49 \pm 0,09$ & $3,71 \pm 0,09$ & $0,98 \pm 0,10$ & $0,46 \pm 0,05$ & $2,79 \pm 0,32$ \\
\hline $\begin{array}{l}2 \text { дослідження } \\
\mathrm{n}-20\end{array}$ & $4,50 \pm 0,27$ & $1,60 \pm 0,07$ & $2,53 \pm 0,14^{*}$ & $0,82 \pm 0,08$ & $0,38 \pm 0,03$ & $2,56 \pm 0,1$ \\
\hline \multicolumn{7}{|c|}{$\begin{array}{c}\text { Показники ліпідного спектру у хворих із ЮІА з високим рівнем ТГ } \\
\text { в динаміці спостереження (через } 12 \text { місяців) }\end{array}$} \\
\hline $\begin{array}{l}1 \text { дослідження } \\
\mathrm{n}-10 \\
\end{array}$ & $5,00 \pm 0,28$ & $1,56 \pm 0,18$ & $2,85 \pm 0,12$ & $1,33 \pm 0,08$ & $0,60 \pm 0,12$ & $2,25 \pm 0,60$ \\
\hline $\begin{array}{l}2 \text { дослідження } \\
\mathrm{n}-10\end{array}$ & $4,65 \pm 0,45$ & $1,50 \pm 0,17$ & $2,39 \pm 0,26$ & $1,69 \pm 0,07 *$ & $0,78 \pm 0,11 *$ & $2,11 \pm 0,1$ \\
\hline \multicolumn{7}{|c|}{$\begin{array}{c}\text { Показники ліпідного спектру у хворих із ЮІА з низьким рівнем ХС ЛПВЩ } \\
\text { в динаміці спостереження (через } 12 \text { місяців) }\end{array}$} \\
\hline $\begin{array}{c}1 \text { дослідження } \\
\mathrm{n}-10\end{array}$ & $4,66 \pm 0,29$ & $0,89 \pm 0,03$ & $2,78 \pm 0,29$ & $1,13 \pm 0,15$ & $0,59 \pm 0,11$ & $3,64 \pm 0,36$ \\
\hline $\begin{array}{l}2 \text { дослідження } \\
\mathrm{n}-10\end{array}$ & $4,36 \pm 0,23$ & $1,66 \pm 0,12 *$ & $2,26 \pm 0,32$ & $0,96 \pm 0,26$ & $0,44 \pm 0,06$ & $1,63 \pm 0,44 * *$ \\
\hline \multicolumn{7}{|c|}{$\begin{array}{l}\text { Показники ліпідного спектру крові на тлі терапії метотрексатом } \\
\text { в динаміці спостереження (через } 12 \text { місяців) } \\
\end{array}$} \\
\hline $\begin{array}{l}1 \text { дослідження } \\
\mathrm{n}-75\end{array}$ & $5,00 \pm 0,11$ & $1,50 \pm 0,06$ & $3,08 \pm 0,15$ & $0,87 \pm 0,03$ & $0,37 \pm 0,02$ & $2,16 \pm 0,15$ \\
\hline $\begin{array}{c}2 \text { дослідження } \\
\mathrm{n}-75\end{array}$ & $4,75 \pm 0,13$ & $1,56 \pm 0,04$ & $2,75 \pm 0,21$ & $1,00 \pm 0,08$ & $0,46 \pm 0,05$ & $2,06 \pm 0,12$ \\
\hline \multicolumn{7}{|c|}{$\begin{array}{l}\text { Показники ліпідного спектру крові на тлі комбінованої базисної терапії } \\
\text { (метотрексат + адалімумаб) в динаміці спостереження (через } 12 \text { місяців) }\end{array}$} \\
\hline $\begin{array}{l}1 \text { дослідження } \\
\mathrm{n}-10\end{array}$ & $4,97 \pm 0,33$ & $1,38 \pm 0,24$ & $3,14 \pm 0,30$ & $1,01 \pm 0,18$ & $0,45 \pm 0,07$ & $2,90 \pm 0,35$ \\
\hline $\begin{array}{c}2 \text { дослідження } \\
\mathrm{n}-10 \\
\end{array}$ & $4,09 \pm 0,22$ & $1,57 \pm 0,16$ & $2,13 \pm 0,21^{*}$ & $0,86 \pm 0,11$ & $0,39 \pm 0,02$ & $1,61 \pm 0,14 * *$ \\
\hline
\end{tabular}

В підгрупі пацієнтів, у яких при першому дослідженні встановлено низький рівень ХС ЛПВЩ (10 осіб), був досить високим рівень ТГ та найвищий рівень КА. У дітей цієї підгрупи встановлено поліартикулярний варіант ЮІА, серопозитивний по АНА, і 50,0 \% дітей отримували комбіновану базисну терапію (метотрексат + адалімумаб). При дослідженні через рік у них відбулось істотне підвищення рівня ХС ЛПВЩ $(\mathrm{p}<$ $0,05)$, тенденція до зниження ХС ЛПНЩ, ХС ЛПДНЩ, а також нормалізація КА (p < $0,01)$. 
Ураховуючи зміни ліпідограм на тлі терапії, ми проаналізували стан ліпідного спектру крові у хворих на ЮІА при динамічному спостереженні 3 урахуванням базисної терапії метотрексатом (MTX). Встановлено, що у цих дітей 3 інтервалом в один рік суттєвих змін в ліпідному спектрі крові не відбулось.

Для 3'ясування впливу біологічної базисної терапії на ліпідний гомеостаз виділена підгрупа дітей, які отримували комбіновану базисну терапію МТX 3 імунобіологічним препаратом (ІБП), а саме блокатором ФНП- $\alpha$ (10 осіб). Слід зазначити, що всі діти з цієї групи хворіли на ЮІА понад три роки, мали серопозитивний по АНА, оліго- (4 дитини) та поліартикулярний (6 пацієнтів) варіант артриту. В цій підгрупі пацієнтів на тлі комбінованої базисної терапії відбувається нормалізація ліпідного спектру крові, а саме - зниження ЗХС, приріст ХС ЛПВЩ, зниження рівня ХС ЛПНЩ $(\mathrm{p}<0,05)$, ТГ та ХC ЛПДНЩ i, як наслідок, значне зниження КА $(\mathrm{p}<0,01)$.

Для виявлення незалежних детермінант, які впливають на формування атерогенних дисліпідемій у дітей, хворих на ЮІА, проведено кореляційний i множинний лінійний регресійний аналіз. При першому дослідженні встановлено достовірні кореляційні зв'язки між підвищеним рівнем антинуклеарних антитіл (маркером автоімунного запалення) та коефіцієнтом атерогенності $(\mathrm{r}=0,68 ; \mathrm{p}<0,05)$ і рівнем ХС ЛПДНЩ $(\mathrm{r}$ $=0,53 ; \mathrm{p}<0,05) ;$ а також прямий середньої сили кореляційний зв'язок між ХС ЛПНЩ та ЦІК $(\mathrm{r}=0,71 ; \mathrm{p}<0,04) . \quad$ Між показниками, що отримані через рік, кореляційні зв'язки не простежуються. Інші ліпідні фракції не показали будь-якої значущої кореляції з маркерами запалення.

В результаті множинного регресійного аналізу 3 покроковим виключенням незначущих перемінних, побудована математична модель прогнозу формування атерогенних дисліпопротеїдемій у дітей, хворих на ЮІА, за даними окремих показників. Їх взаємозалежність при першому дослідженні була представлена наступними формулами:

ХС ЛПНЩ $=3,9184+0,0974494 *$ ANA $+3,46668^{*}$ ЦІК $+0,568087^{*}$ ФГ

$$
\begin{gathered}
\left(\mathrm{R}=94,68 \% ; \mathrm{R}^{2}=87,58 \% ; \mathrm{p}<0,02\right) . \\
\text { ТГ }=0,0550007+0,281653 * \mathrm{ANA}+ \\
0,153077 \text { ЦЦК }+0,00740288^{*} \text { ФГ } \\
\left(\mathrm{R}=84,27 \% ; \mathrm{R}^{2}=74,83 \% ; \mathrm{p}<0,01\right) .
\end{gathered}
$$

Згідно з формулами, рівні ХС ЛПНЩ та ТГ, які $є$ проатерогенними фракціями ліпідного спектру крові, у дітей хворих на ЮІА, залежать від маркерів запальної активності патологічного процесу 3 високою прогнозованою точністю, про що свідчать коефіцієнти детермінації $(\mathrm{R}=$ $87,58 \%$ та $\mathrm{R}^{2}=74,83 \%$; відповідно).

При дослідженні через рік дані закономірності були відсутні, коефіцієнти детермінації склали для ХС ЛПНЩ лише: $\mathrm{R}=32,22 \%$ та $\mathrm{R}^{2}=15,08 \% ; \mathrm{p}>0,7$; для ТГ $\mathrm{R}=46,90 \%$ та $\mathrm{R}^{2}=34,50 \% ; \mathrm{p}>0,5$.

\section{ОБГОВОРЕННЯ РЕЗУЛЬТАТІВ ДОСЛІДЖЕННЯ}

Відомо, що ураження судин при наявності дисліпідемій в дитячому віці $\epsilon$ дуже незначними i ïx прогресування у більшості пацієнтів відбувається повільно із малою швидкістю. Отримані результати підтвердили наявність у дітей з ЮІА на тлі хронічного запального процесу субклінічних ознак атеросклерозу, що може виявлятися вже на ранніх етапах захворювання $[4,5]$ i, в свою чергу, можуть змінюватись більш інтенсивно. При наявності запалення метаболізм ліпідів значно ускладнюється, особливо при автоімунних захворюваннях, i виникають порушення ліпідного обміну зі зміщенням ліпідного спектру крові у бік атерогенних фракцій.

Високий рівень $3 \mathrm{XC}, \mathrm{XC} \mathrm{ЛПНЩ,} \mathrm{ТГ} \mathrm{і}$ низький рівень ХC ЛПВЩ $є$ ознаками атерогенних дисліпідемій. Зазначені зміни у дорослих пацієнтів із ревматоїдним артритом реєструються навіть до появи виражених клінічних його проявів, що показано в ретроспективних дослідженнях [6]. Проведене дослідження також показало, що i у дітей 3 ЮIА, відбуваються вищевказані зміни ліпідного спектру крові, присутні всі зазначені складові формування атеросклерозу. Разом 3 тим, не зафіксовано проявів «ліпідного парадоксу», що співпадає 3 думкою окремих авторів, які не знаходять даний феномен у дітей та підлітків [18]. 
Вивчення динаміки змін фракційного складу ліпідного спектру крові у дітей із ЮІА за умов подальшого його розвитку та лікування виявило загалом позитивні зсуви. Незважаючи на провідний чинник формування атерогенних дисліпопротеїдемій, на тлі базисної протиревматичної терапії у дітей відмічається зниження або нормалізація КА. Однак, пацієнти, які при первинному дослідженні мають підвищені ТГ, не показали суттєвих позитивних змін, що дозволяе вважати саме такий тип дисліпопротеїдемії найбільш несприятливим.

Разом 3 тим, додатковий вплив на ліпідний спектр крові у дорослих хворих на РА мають препарати, що входять до групи протизапальних засобів. Використання МTX пов'язують зі зменшенням ризику розвитку серцево-судинних ускладнень, пов'язаних з атеросклерозом, в діапазоні від $15 \%$ до $85 \%$ [13]. Останні дослідження показали значне зниження частоти летальних серцево-судинних подій на тлі використання інгібіторів ФНП- $\alpha[14,15,16]$. Відомо також, що терапія інгібіторами ФНП- $\alpha$ здійснює потенційний кардіоза-хистний ефект, як у дорослих хворих, так й у дітей з ЮІА [17].

Отримані результати дозволяють констатувати, що монотерапія ЮІА метотрексатом не $\epsilon$ достатньою у всіх дітей для нормалізації ліпідного спектру. Лише на тлі комбінованої базисної терапії (MTX + ІБП) відбувається нормалізація вмісту фракцій ліпідного спектру крові, а саме - зниження 3ХС, приріст ХС ЛПВЩ, зниження рівня ХС ЛПНЩ (p<0,05), ТГ та ХC ЛПДНЩ i, як наслідок, значне зниження КА $(\mathrm{p}<0,01)$. Це підкреслює необхідність використання комбінованої базисної терапії (МТХ + ІБП) не тільки для лікування резистентних варіантів перебігу ЮІА, а й з метою попередження розвитку коморбідних станів і поліпшення віддаленого прогнозу юних пацієнтів 3 артритом.

Відомо, що однією з ознак високої імунозапальної активності хвороби $\epsilon$ підвищений рівень $Ф Г$, що є також ланкою тромбоутворення на тлі активності запального процесу. Наявність цього показника в регресійній моделі підтердило його клінічне i прогностичне значення [18]. У той же час, на тлі базисної імуносупресивної терапії та при зниженні запальної активності хвороби кореляційні зв'язки показників ліпідограми із показниками активності процесу порушуються.

\section{ВИСНОВКИ}

1. У дітей, хворих на ЮІА, відбувається формування атерогенних змін ліпідного спектру крові на тлі активного запального процесу.

2. Призначення базисної імуносупресивної терапії при ідіопатичному артриті у дітей призводить до зниження запалення i нормалізації ліпідного спектру. Більш виразний ефект у лікуванні таких хворих відмічено при застосуванні комбінації метотрексату 3 імунобіологічним препаратом (анти-ФНП).

\section{ПЕРСПЕКТИВИ ПОДАЛЬШИХ ДОСЛІДЖЕНЬ}

Видокремити групу пацієнтів 3 прогресуванням змін ліпідного спектру або зі збереженням цих змін на тлі терапії після іiі корекції та інтенсифікації. Встановити причини цих змін.

\section{ФІНАНСУВАННЯ}

Робота виконана в рамках наукової роботи ДУ «Інститут охорони здоров'я дітей та підлітків НАМН України», номер держреєстрації: НАMН 88/16 0118U003186.

\section{СПИСОК ЛІТЕРАТУРИ}

1. Zhang J., Chen L., Delzell E., Muntner P., Hillegass W. et al. The association between inflammatory markers, serum lipids and the risk of cardiovascular events in patients with rheumatoid arthritis. Ann Rheum Dis. 2014; 73 (7): 1301-1308. https://doi.org/10.1136/annrheumdis-2013-204715.

2. Skeoch S., Bruce I. N. Atherosclerosis in rheumatoid arthritis: is it all about inflammation? Nat Rev Rheumatol. 2015; 11 (7): 390-400. https://doi.org/10.1038/nrrheum.2015.40.

3. Gabriel S. E., Crowson C. S. Risk factors for cardiovascular disease in rheumatoid arthritis. Curr Opin Rheumatol. 2012; 24 (2): 171-176. https://doi.org/10.1097/bor.0b013e32834ff2fd. 
4. Coulson E. J., Ng W-F, Goff I., Foster H. E. Cardiovascular risk in juvenile idiopathic arthritis. Rheumatology. 2013: 52 (7): 1163-1171. https://doi.org/10.1093/rheumatology/ket106.

5. Nadkarni A., You M., Resuehr H., Curtis J. R. The risk for cardiovascular events associated with hyperlipidemia among patients with and without rheumatoid arthritis. J. Arthritis. 2015; 4 (40): 178. https://doi.org/10.4172/2167-7921.1000178.

6. Erum U., Ahsan T., Khowaja D. Lipid abnormalities in patients with rheumatoid arthritis. Pak J Med Sci. 2017; 33 (1): 227-230. https://doi.org/10.12669/pjms.331.11699.

7. Myasoedova E., Crowson C. S., Kremers H. M., Roger V. L., Fitz-Gibbon P. D. et al. Lipid paradox in rheumatoid arthritis: the impact of serum lipid measures and systemic inflammation on the risk of cardiovascular disease. Ann Rheum Dis. 2011; 70 (3): 482-487. https://doi.org/10.1136/ard.2010.135871.

8. Amezaga U. M., Suarez-Almazor M. E. Lipid paradox in rheumatoid arthritis: changes with rheumatoid arthritis therapies. Curr Rheumatol Rep. 2012; 14 (5): 428-437.

https://doi.org/10.1007/s11926-012-0269-z.

9. Mackey R. H., Kuller LH., Moreland L. W. Update on cardiovascular disease risk in patients with rheumatic diseases. Rheum Dis Clin North Am. 2018; 44 (3): 475-487. https://doi.org/10.1016/j.rdc.2018.03.006.

10. Södergren A., Karp K., Boman K., Eriksson C., Smedby T. et al. Atherosclerosis in early rheumatoid arthritis: very early endothelial activation and rapid progressi on of intima media thickness Arthritis Res Ther. 2010; 12 (4): R158. https://dx.doi.org/10.1186\%2Far3116.

11. Коваленко В. М., Лисенко Г. І., Хіміон Л. В., Гарміш О. О. Вплив медикаментозної терапії на прогресування субклінічного атеросклерозу та розвиток судинних ускладнень у хворих на ревматоїдний артрит. Укр. ревматол. журн. 2012; 1 (47): 12-17.

https://www.rheumatology.kiev.ua/wp/wp-content/uploads/2012/02/47_12-18.pdf?upload=.

12. Бережний В. В., Романкевич І. В. Ювенільний ревматоїдний артрит і атеросклероз: нові погляди на два захворювання. Современная педиатрия. 2011; 5 (39): 126-129.

https://www.researchgate.net/publication/299487359_Uvenilnij_revmatoidnij_artrit_i_ateroskleroz_novi_ pogladi_na_dva_zahvoruvanna.

13. Robertson J., Peters M. J., McInnes I. B., Sattar N. Changes in lipid levels with inflammation and therapy in RA: a maturing paradigm. Nat Rev Rheumatol. 2013; 9: 513-523.

https://doi.org/10.1038/nrrheum.2013.91.

14. Shepherd J, Cooper K, Harris P, Picot J, Rose M. The clinical effectiveness and cost-effectiveness of abatacept, adalimumab, etanercept and tocilizumab for treating juvenile idiopathic arthritis: a systematic review and economic evaluation. Health Technol Assess. 2016; 20 (34): 1-222. https://doi.org/10.3310/hta20340.

15. Favalli E. G., Pontikaki I., Becciolini A., Biggioggero M., Ughi N. et al. Real-life 10-year retention rate of first-line anti-TNF drugs for inflammatory arthritides in adult- and juvenile-onset populations: similarities and differences. Clin Rheumatol. 2017; 36 (8): 1747-1755. https://doi.org/10.1007/s10067-017-3712-8.

16. Rochette E., Bourdier P., Pereira B., Dore E., Birat A. et al. TNF blockade contributes to restore lipid oxidation during exercise in children with juvenile idiopathic arthritis. Pediatr Rheumatol Online J. 2019; 17 (1): 47. https://doi.org/10.1186/s12969-019-0354-1.

17. Verstegen RHJ, McMillan R, Feldman B. M., Ito S, Laxer R. M. Towards therapeutic drug monitoring of TNF inhibitors for children with juvenile idiopathic arthritis: a scoping review. Rheumatology (Oxford). 2020; 59 (2): 386-397. https://doi.org/10.1093/rheumatology/kez285.

18. Bag-Ozbek A., Giles J. T. Inflammation, adiposity and atherogenic dyslipidemia in rheumatoid arthritis: is there a paradoxical relationship? Curr Allergy Asthma Rep. 2015; 15 (2): 497. https://doi.org/10.1007/s11882-014-0497-6.

\section{REFERENCES}

1. Zhang, J, Chen, L, Delzell, E, Muntner, P, Hillegass, WB., Safford, MM., Millan, IY, Crowson, CS. \& Curtis, JR. The association between inflammatory markers, serum lipids and the risk of cardiovascular events in patients with rheumatoid arthritis. Ann Rheum Dis. 2014; 73 (7): 1301-1308. https://doi.org/10.1136/annrheumdis-2013-204715.

2. Skeoch S, Bruce IN. Atherosclerosis in rheumatoid arthritis: is it all about inflammation? Nat Rev Rheumatol. 2015; 11 (7): 390-400. https://doi.org/10.1038/nrrheum.2015.40.

3. Gabriel SE, Crowson CS. Risk factors for cardiovascular disease in rheumatoid arthritis. Curr Opin Rheumatol. 2012; 24 (2): 171-176. https://doi.org/10.1097/bor.0b013e32834ff2fd.

4. Coulson EJ, Ng W-F, Goff I \& Foster HE. Cardiovascular risk in juvenile idiopathic arthritis. Rheumatology. 2013; 52 (7): 1163-1171. https://doi.org/10.1093/rheumatology/ket106. 
5. Nadkarni A, You M, Resuehr H \& Curtis J R. The risk for cardiovascular events associated with hyperlipidemia among patients with and without rheumatoid arthritis. J. Arthritis. 2015;4(40):178. https://doi.org/10.4172/2167-7921.1000178.

6. Erum U, Ahsan T. \& Khowaja D. Lipid abnormalities in patients with rheumatoid arthritis. Pak J Med Sci. 2017; 33 (1): 227-230. https://doi.org/10.12669/pjms.331.11699.

7. Myasoedova E, Crowson CS, Kremers HM., Roger VL, Fitz-Gibbon PD, Therneau TM. \& Gabriel SE. Lipid paradox in rheumatoid arthritis: the impact of serum lipid measures and systemic inflammation on the risk of cardiovascular disease. Ann Rheum Dis. 2011; 70 (3): 482-487. https://doi.org/10.1136/ard.2010.135871. [in Russian].

8. Amezaga UM, Suarez-Almazor ME. Lipid paradox in rheumatoid arthritis: changes with rheumatoid arthritis therapies. Curr Rheumatol Rep. 2012;14(5):428-437. https://doi.org/10.1007/s11926-012-0269-z.

9. Mackey RH, Kuller LH. \& Moreland LW. Update on cardiovascular disease risk in patients with rheumatic diseases. Rheum Dis Clin North Am. 2018; 44 (3): $475-487$. https://doi.org/10.1016/j.rdc.2018.03.006.

10. Södergren A, Karp K, Boman K, Eriksson C, Lundström E, Smedby T, Söderlund L, RantapääDahlqvist S. \& Wållberg-Jonsson, S. Atherosclerosis in early rheumatoid arthritis: very early endothelial activation and rapid progressi on of intima media thickness. Arthritis Res Ther. 2010; 12 (4): R158. https://dx.doi.org/10.1186\%2Far3116.

11. Kovalenko VM, Lysenko HI, Khimion LV. \& Harmish OO. Vplyv medykamentoznoi terapii na prohresuvannia subklinichnoho aterosklerozu ta rozvytok sudynnykh uskladnen u khvorykh na revmatoidnyi artryt [The effect of drug therapy on the progression of subclinical atherosclerosis and the development of vascular complications in patients with rheumatoid arthritis]. Ukrainian journal of rheumatology. 2012; 1 (47): 12-17. content/uploads/2012/02/47_12-18.pdf?upload=. [in Ukrainian].

12. Berezhnyi VV, Romankevych IV. Yuvenilnyi revmatoidnyi artryt i ateroskleroz: novi pohliady na dva zakhvoriuvannia [Juvenile rheumatoid arthritis and atherosclerosis: new perspectives on two diseases]. Modern Pediatrics. 2011; 5 (39): 126-129.

https://www.researchgate.net/publication/299487359_Uvenilnij_revmatoidnij_artrit_i_ateroskleroz_novi_ pogladi_na_dva_zahvoruvanna. [in Ukrainian].

13. Robertson J, Peters MJ, McInnes IB. \& Sattar N. Changes in lipid levels with inflammation and therapy in RA: a maturing paradigm. Nat Rev Rheumatol. 2013; 9: 513-523. https://doi.org/10.1038/nrrheum.2013.91.

14. Shepherd J, Cooper K, Harris P, Picot J. \& Rose, M. The clinical effectiveness and cost-effectiveness of abatacept, adalimumab, etanercept and tocilizumab for treating juvenile idiopathic arthritis: a systematic review and economic evaluation. Health Technol Assess. 2016; 20 (34): 1-222. https://doi.org/10.3310/hta20340.

15. Favalli EG, Pontikaki I, Becciolini A, Biggioggero M, Ughi N, Romano M, Crotti Ch, Gattinara M, Gerloni V, Marchesoni A. \& Meroni PL. Real-life 10-year retention rate of first-line anti-TNF drugs for inflammatory arthritides in adult- and juvenile-onset populations: similarities and differences. Clin Rheumatol. 2017; 36 (8): 1747-1755. https://doi.org/10.1007/s10067-017-3712-8.

16. Rochette E, Bourdier P, Pereira B, Dore E, Birat A, Ratel S, Echaubard S, Duche P. \& Merlin E. TNF blockade contributes to restore lipid oxidation during exercise in children with juvenile idiopathic arthritis. Pediatr Rheumatol Online J. 2019; 17 (1): 47. https://doi.org/10.1186/s12969-019-0354-1.

17. Verstegen RHJ, McMillan R, Feldman BM, Ito S. \& Laxer, RM. Towards therapeutic drug monitoring of TNF inhibitors for children with juvenile idiopathic arthritis: a scoping review. Rheumatology (Oxford). 2020; 59 (2): 386-397. https://doi.org/10.1093/rheumatology/kez285.

18. Bag-Ozbek A, Giles, JT. Inflammation, adiposity and atherogenic dyslipidemia in rheumatoid arthritis: is there a paradoxical relationship? Curr Allergy Asthma Rep. 2015; 15 (2): 497. https://doi.org/10.1007/s11882-014-0497-6

\section{DYNAMICS OF BLOOD LIPID SPECTRUM INDICATORS IN CHILDREN WITH JUVENILE IDIOPATHIC ARTHRITIS TAKING INTO ACCOUNT BASIC THERAPY}

Bohmat L. F., Nikonova V. V., Shevchenko N. S., Holovko T. O., Bessonova I. M.

Summary. In patients with rheumatoid arthritis, the risk of cardiovascular disease associated with atherosclerosis, is significantly increased compared to the general population. Studies of a cohort of children and young adults indicated that the atherosclerotic process usually begins long before its clinical manifestation, and the degree of vascular changes is associated with both the number of risk factors and their 
severity. The use of basic drugs in rheumatic patients contributed to a decrease in cardiovascular mortality, mainly due to the elimination of the activity of the process, which itself is an inducer of the onset and progression of atherosclerosis.

The aim of the study was to establish the nature of changes in the blood lipid spectrum in children with juvenile idiopathic arthritis under the influence of basic therapy.

Object and methods. We examined 85 children (8-18 years old) with juvenile idiopathic arthritis and oligo- $(61.5 \%)$ and polyarticular $(38.5 \%)$ variants of the disease, twice, with an interval of one year. The parameters of the blood lipid spectrum were determined by the level of: total cholesterol, triglycerides, high density lipoproteins, atherogenic coefficient by the enzymatic method on an automatic biochemical analyzerphotometer A25, low lipoproteins and very low density cholesterol by calculation method.

Research results. Analysis of the lipid profile in the group as a whole showed that patients with juvenile idiopathic arthritis had significantly higher total cholesterol values $(\mathrm{p}<0.05)$, a tendency to an increase in the level of triglycerides, low lipoproteins and very low density cholesterol, which led to an increase in the atherogenic coefficient level. When analyzing the lipid spectrum of blood after a year, a tendency towards a decrease in the level of atherogenic and an increase in antiatherogenic fractions of the lipid spectrum with normalization of atherogenic coefficient was noted. In the group of patients receiving monotherapy with methotrexate, no significant changes in the lipid spectrum of blood were observed after one year. Against the background of combined basic therapy, the blood lipid spectrum normalizes, namely, a decrease in total cholesterol, an increase in high density lipoproteins of cholesterol, a decrease in the level of low density cholesterol $(\mathrm{p}<0.05)$, triglycerides and very low density cholesterol and, as a consequence, significant decrease in atherogenic coefficient $(\mathrm{p}<0.01)$.

Conclusions. The dynamics of changes in blood lipid spectrum indicators in children with juvenile idiopathic arthritis confirms the need to use combined basic therapy not only to control the activity of main pathological process, but also to prevent the development of atherogenic dyslipoproteinemias.

KEY WORDS: juvenile idiopathic arthritis, lipid spectrum, therapy, children

\section{INFORMATION ABOUT AUTHORS}

Bogmat Ludmila, MD, PhD, Professor, Head of the Department of rheumatology and comorbid conditions, State Institution «Institute for the Health of Children and Adolescents of the National Academy of Medical Sciences of Ukraine», Yubileiny avenue, 52 A, Kharkiv, Ukraine, 61118; MD, Professor of pediatric department № 2, V. N. Karazin Kharkiv National University, Svobody Sq., 4, Kharkiv, Ukraine, 61022, e-mail: bogmatLF@gmail.com, ORCID ID: https://orcid.org/0000-0001-5144-3686

Nikonova Viktoria, PhD, senior researcher, Department of rheumatology and comorbid conditions, SI «Institute for Children and Adolescents Health Care of the NAMS of Ukraine», Yubileiny avenue, 52 A, Kharkiv, Ukraine, 61118, e-mail: viktoriavvn@ @mail.com, ORCID ID: https://orcid.org/0000-0001-8269-6176

Shevchenko Natalya, MD, PhD, Professor, head of pediatric department № 2, V. N. Karazin Kharkiv National University, Svobody Sq., 4, Kharkiv, Ukraine, 61022; MD, leading research worker of Department of rheumatology and comorbid conditions State Institution «Institute for the Health of Children and Adolescents of the National Academy of Medical Sciences of Ukraine», Yubileiny avenue, $52 \mathrm{~A}$, Kharkiv, Ukraine, 61118, e-mail: natalia.shevchenko@karazin.ua, ORCID: https://orcid.org/0000-0003-4407-6050

Holovko Tetiana, PhD, associate professor, department of pediatric № 2, V. N. Karazin Kharkiv National University, Svobody Sq., 4, Kharkiv, Ukraine, 61022. e-mail: golovko@karazin.ua, ORCID ID: https://orcid.org/0000-0003-38157874

Bessonova Irina, senior researcher, department of rheumatology and comorbid conditions, SU «Institute for Children and Adolescents Health Care at the National Academy of Medical Sciences of Ukraine», Yubileiny avenue, 52 A, Kharkiv, Ukraine, 61118, Associate Professor at the Department of Pediatrics V. N. Karazin Kharkiv National University, Svobody Sq., 4, Kharkiv, Ukraine, 61022. e-mail: irina_bessonova@yahoo.com, ORCID ID: https://orcid.org/0000-0002-84738365

\section{ДИНАМИКА ПОКАЗАТЕЛЕЙ ЛИПИДНОГО СПЕКТРА КРОВИ У ДЕТЕЙ С ЮВЕНИЛЬНЫМ ИДИОПАТИЧЕСКИМ АРТРИТОМ С УЧЕТОМ БАЗИСНОЙ ТЕРАПИИ}

Богмат Л. Ф., Никонова В. В., Шевченк Н. С., Головко Т.А., Бессонов И. Н.

Резюме. У пациентов с ревматоидным артритом риск сердечно-сосудистых заболеваний, связанных с атеросклерозом, значительно увеличивается по сравнению с общей популяцией. Исследования когорты детей и молодых взрослых свидетельствуют о том, что атеросклеротический процесс, как правило, начинается задолго до его клинической манифестации, а степень изменений сосудов связана как с количеством факторов риска, так и с их выраженностью. Использование 
базисных препаратов у ревматических больных способствовало снижению кардиоваскулярной смертности, преимущественно за счет ликвидации активности процесса, который сам по себе является индуктором возникновения и прогрессирования атеросклероза.

Цель исследования - установить характер изменений липидного спектра крови у детей с ювенильным идиопатическим артритом под влиянием базисной терапии.

Объект и методы. Обследовано 85 детей (8-18 лет), больных ювенильным идиопатическим артритом с олиго- (61,5\%) и полиартикулярним (38,5\%) вариантами заболевания, дважды, с интервалом в 1 год. Показатели липидного спектра крови определяли по уровню: общего холестерина, триглицеридов, холестерина липопротеидов высокой плотности, коэффициента атерогенности ферментативным методом на биохимическом автоматическом анализаторе-фотометре А25, холестерина липопротеидов низкой и очень низкой плотности расчетным методом.

Результаты исследования. Анализ липидограммы в целом по группе показал, что у пациентов с ювенильным идиопатическим артритом достоверно выше были показатели общего холестерина $(\mathrm{p}<$ 0,05), тенденция к повышению уровня триглицеридов, холестерина липопротеидов низкой и очень низкой плотности, что приводило к росту уровня коэффициента атерогенності. При анализе липидного спектра крови через год отмечена тенденция к снижению уровня атерогенных и повышению антиатерогенных фракций липидного спектра с нормализацией коэффициента атерогенності. В группе больных, получавших монотерапию метотрексатом, через один год существенных изменений в липидном спектре крови не отмечалось. На фоне комбинированной базисной терапии происходит нормализация липидного спектра крови, а именно - снижение общего холестерина, прирост холестерина липопротеидов высокой плотности, снижение уровня холестерина липопротеидов низкой плотности ( $<0,05)$, триглицеридов и холестерина липопротеидов очень низкой плотности и, как следствие, значительное снижение коэффициента атерогенності ( $\mathrm{p}<0,01)$.

Выводы. Динамика изменений показателей липидного спектра крови у детей с ювенильным идиопатическим артритом подтверждает необходимость использования комбинированной базисной терапии не только для контроля основного патологического процесса, но и для профилактики развития атерогенных дислипопротеидемий.

КЛЮЧЕВЫЕ СЛОВА: ювенильный идиопатический артрит, липидный спектр, терапия, дети

\section{ІНФОРМАЦИЯ ОБ АВТОРАХ}

Богмат Людмила Феодосиевна, д. мед. н., профессор, зав. отделом ревматологии и коморбидных состояний, ГУ «Институт охраны здоровья детей и подростков НАМН Украины», Украина, Харьков, проспект Юбилейный, 52 A, 61118; д. мед. н, профессор кафедри педиатрии № 2, Харьковский национальный университет имени В. Н. Каразина, площадь Свободы, 4, Харьков, Украина, 61022. e-mail: bogmatLF@gmail.com, ORCID ID: https://orcid.org/0000-0001-5144-3686

Никонова Виктория Вадимовна, к. мед. н., старший научный сотрудник отдела ревматологии и коморбидных состояний, ГУ «Институт охраны здоровья детей и подростков НАМН Украины», проспект Юбилейный, 52 А, Харьков, Украина, 61118. e-mail: viktoriavvn@gmail.com, ORCID ID: https://orcid.org/0000-0001-8269-6176

Шевченко Наталья Станиславовна, д. мед. н., зав. кафедри педиатрии № 2, Харьковский национальный университет имени В. Н. Каразина, площадь Свободы, 4, Харьков, Украина, 61022, д. мед. н., ведущий научный сотрудник отдела ревматологии и коморбидных состояний, ГУ «Институт охраны здоровья детей и подростков НАМН Украины», проспект Юбилейный, 52 А, Харьков, Украина, 61118. e-mail: natalia.shevchenko@karazin.ua, ORCID ID: https://orcid.org/0000-0003-4407-6050

Головко Татьяна Алексеевна, к. мед. н., доцент каф. педиатрии № 2, Харьковский национальный университет имени В. Н. Каразина, площадь Свободы, 4, Харьков, Украина, 61022. e-mail: golovko@karazin.ua, ORCID ID: https://orcid.org/0000-0003-3815-7874

Бессонова Ирина Николаевна, старший научный сотрудник отдела ревматологии и коморбидных состояний, ГУ «Институт охраны здоровья детей и подростков НАМН Украины», проспект Юбилейный, 52 А, Харьков, Украина, 61118, доцент кафедры педиатрии, Харьковский национальный университет имени В. Н. Каразина, площадь Свободы, 4, Харьков, Украина, 61022. e-mail: irina_bessonova@yahoo.com, ORCID ID: https://orsid.org/0000-0002-8473-8365

Conflicts of interest: author has no conflict of interest to declare.

Конфлікт інтересів: відсутній.

Конфликт интересов: отсутствует. 